\title{
RECRUITMENT AND MANIPULATION IN THE ROMAN WORLD
}

\author{
Cosmin Onofrei
}

\begin{abstract}
Recrutare şi manipulare în lumea romană
Armata romană a beneficiat atât în trecut cât şi în prezent de numeroase studii, fiind un subiect care a fascinat savanții din toate colțurile lumii. La momentul actual dispunem de lucrări ce ne prezintă structura armatei, modul de recrutare în cadrul său, ascensiunea în mediul militar şi diversele grade existente, precum şi informații utile referitoare la plata, alimentația, ocupațiile sau lăsarea la vatră a militarilor. În marea lor parte aceste studii, foarte bine documentate, prezintă datele doar din perspectiva Romei, şi anume necesitatea Imperiului de a menține o armată competitivă în toate zonele de graniță. Pe de altă parte, impactul şi implicațiile ulterioare pe care recrutarea le avea asupra societăților care ofereau recruți au fost puțin comentate de majoritatea autorilor. Situația existentă urmează a fi prezentată din perspectiva a patru populații, diferite una de alta, dar care în trecut fuseseră legate toate de Roma printrun foedus. Cele patru exemple le reprezintă batavii, palmyrenii, maurii şi goții.
\end{abstract}

Key words: Recruitment, Manipulation, Foedus, Gentes, Auxilia.

The Roman army benefited both in the past as well as the present of numerous studies, being a subject that fascinated scholars around the world. Currently, works discussing the army structure, recruitment means, military careers and various existent ranks, as well as useful information regarding the pays, food, activities and soldiers' discharge are available. The majority, very well documented, present data only from Rome's view, i.e. the Empire's necessity to maintain a competitive army in all its frontier regions. On the other hand, subsequent impact and consequences that enrolment had on societies providing recruits were less commented by most authors. The present study intends precisely to observe this phenomenon with several populations.

Starting from the above statement, we wish to present the existent situation, as appropriately as possible under present circumstances, from the perspective of four populations, different one from the other and originating from various areas of the Empire, all related to Rome in the past by a foedus. The four examples are the Batavians, the Palmyrenes, the Mauri and the Goths. Thus, we shall attempt to discern both the recruitment impact over such populations as well as the evolution in time of their relations with the Empire.

Relations between the Romans and the populations beyond the limes were consecrated by a series of covenants named in Latin foedera (sing. foedus). Although only pledges of the 4th $\mathrm{C} \mathrm{AD}$, like the one for instance closed with the Goths in AD 332, are recorded within sources under the Latin term foedera, they were closed in accordance with much more earlier models, since Barbarian allies outside Empire borders (symmachoi) fighting under the command of a native related to Rome also by a foedus, should be deemed foederati ${ }^{1}$.

\footnotetext{
${ }^{1}$ Heather 1997, 57; Graf 1998, 18-19 consider that during the early period of the Principate, the term may be applied to Barbarian irregular units serving temporarily only.
} 


\section{THE BATAVIANS}

Among German tribes that contributed to the increase of Roman strength, the Batavians are notable both by the great number of recruited units $(8 \text { cohorts and } 1 \text { ala })^{2}$ and their bravery, classical sources mentioning they represented an amphibious force, succeeding to swim across rivers together with the attached equipment ${ }^{3}$. They do not lack from prestigious units either, Batavian soldiers being recorded among corporis custodes at Rome ${ }^{4}$.

Roman contacts with the Batavians are as early as Augustus's rule. Agrippa ${ }^{5}$ was the first who tried to use the military potential of various local groups in order to consolidate the conquered territory by relocating them to the left bank of the Rhine, thus a series of tribes were settled within the Empire. This is also the case of the Batavians ${ }^{6}$. Moreover, Tacitus informes us on their status noting that they were tax exempted as they, often regularly, provided recruits serving under their own officers, a fact consecrated by a vetus institutum?

We must underline that the Batavians provided recruits based on a foedus with Rome that must have been in force from under Augustus. They were led by their own officers, who were in fact members of the local aristocracy, fact confirmed by another passage in Tacitus ${ }^{8}$. The text infers that Batavian cohorts from Britannia were led by Iulius Civilis and Claudius Paulus. The two came from among the Batavian aristocrats and were brothers.

The information is useful for the discussion herein also from other standpoints. Firstly, we notice that local elites were incorporated within this system, the auxiliaries command leading to the change of Batavians leaders into military Roman leaders. Secondly, if brothers, coming from the upper-class, served in the Roman army we may imagine the same in the case of lower classes.

The massive recruitment of the Batavians had a series of implications. It is known that the community preferred shepherding instead of intensive farming. This practice was in concurrence with the life of warrior societies, which by definition adopt a pastoral economy that does not require much labour when many were campaigning. Moreover, it is estimated that the Batavian population rised to $30.000-40.000$ individuals dwelling $4000-6000$ houses $^{9}$. Given the high number of recruited troops ( 8 cohorts, 1 ala, soldiers in the fleet and at Rome), the community was definitely under the pressure of Roman authorities.

Although the Batavians enter in contact with the Romans early, until the arrival of legion X Gemina in the area, archaeological finds do not certify, except very poorly, the existence of Roman goods, while only Oppidum Batavorum resembled a city. Scarce Roman artifacts in the area are related to the native elite and probably to certain soldiers ${ }^{10}$. Likewise, the community is granted municipal rights rather late, no sooner than the second half of the 2nd $\mathrm{C} \mathrm{AD}^{11}$.

\footnotetext{
${ }^{2}$ Holder 1980, appendix III: only nervi (6 cohorts) and tungri (2 alae and 4 cohorts) are similar in number.

${ }^{3}$ Tacitus, Annales, II, 11, 1; Germania 29; Cassius Dio 60. 20, 69, 9, 6; CIL III 3676.

${ }^{4}$ Speidel 1992, 105-119; Birley 2002, 43, 66; Saddington 2005, 65, note 21; Derks 2009, 242.

${ }^{5}$ Saddington 1975, 191 chooses Drusus.

${ }^{6}$ Derks 1997, 37-38; Roymans 1983, 57. Caesar's war in Gallia, which led to the annihilation of Belgian tribes in the Lower Rhine area, facilitated Roman contact with northerner peoples, like the Batavians and the Cananefatii.

${ }^{7}$ Tacitus, Hist., IV, 12.

${ }^{8}$ Tacitus, Hist., IV, 12-13.

${ }^{9}$ Willems 1984, 234-237; Haynes 2001, 68-71.

${ }^{10}$ Van Enckevort 2005, 85.

${ }^{11}$ Raepsaer-Charlier 1995, 366-369.
} 
Lastly, we should also mention the alteration of ritual practices and religious concepts, ritual weaponry deposits ceasing under Augustus in the south-west and subsequently in the north with several communities. Practically, old traditions lose significance ${ }^{12}$.

The impact of successive recruitment over the Batavian society was strong and to the detriment of its development, both economical and spiritual, since changes taking place within the community did not incur advances, like for instance the adoption of Roman life style or imitation of Mediterranean urbanism. Tax collection is not signalled even after the AD $69-70^{13}$ revolt, which makes us believe that the Romans deemed recruitment more profitable than taxation, the supplied bodies being more important than taxes levied from a not very rich area ${ }^{14}$. Simpler said, the recruitment policy was continued by Rome for its lucrativeness, little being invested in exchange to peace and recruits.

\section{THE PALMYRENES}

Moving away from northern regions, we shall focus on the eastern part of the Empire, more exactly on Palmyra. Although the history of the city conquered by Aurelian is better known after the ascension of Septimius Odaenathus, hereinafter we shall try to specify a few aspects related to its origins. It is certain that the grand colonnades and other architectonical marvels did not exist in AD 41 when Marcus Antonius sends troops to punish the Palmyrenes who traded with the two empires ${ }^{15}$. The population did not await the Roman attack and crossed the Euphrates in order to defend itself more efficiently. The population's reaction to run across the Euphrates indicates easiness of movement from one place to the other and moreover, shows that the city was not provided with a surrounding wall at the date ${ }^{16}$.

For the discussion herein, it is interesting to learn Palmyra's status. It is clear that in AD 41, a proper city did not exist there. However, there is epigraphic information ${ }^{17}$ on a border between Palmyra and Emesa, while a regio Palmyrena, established by Creticus Silanus (AD 11-17), legate of Syria is also signalled. Most likely, the city paid tribute and should be seen as a territorial integral part of the Empire ${ }^{18}$. On the other hand, Palmyra should not be seen as a city belonging territorially to the province of Syria, alike Apameia or Antiochia. The territorial integration of a city within a province supposes a series of military, financial and legal changes. The military aspect consists in the attachment of a garrison and the supply of recruits to the Roman army ${ }^{19}$. Hence, this is not the case of Palmyra until second half of the 2 nd $\mathrm{C}$, as only then, ala I Ulpia singul(arium) whose commander, C. Vibius Celer is honoured several times ${ }^{20}$ is recorded.

\footnotetext{
${ }^{12}$ Derks 1997, 50; For complete discussion on graves furniture, the society's warlike ideology, as well as upper class influence on lower class concerning burial fashion, see: Roymans 1990, 224-254 with a series of defining tables.

13 Alföldy 1968, 45-48; Haynes 2001, 68; Van Enckevort 2005, 85 see the Batavian cohorts participating in the conquest of Britannia under Claudius as regular auxiliaries; Cheesman 1914, 72, note 2; Knight 1991, 1995, note 12 reminds however that Batavian pedestrian troops partaking prior AD 69 the campaign in Britannia, served still under own officers, thus proving they no longer enjoyed the status of a cohort and that their integration in the Roman auxiliary system occurs only under Vespasian. Birley 2002, 44 mentions that the status and privileges of the Batavian aristocracy, including the command of their own troops, are maintained subsequent the uprising.

${ }^{14}$ The Batavians recruitment in own ethnical units lasts at most until the beginning of the 2nd C AD, Derks 2009, 243, note 19; RMD IV 216.

${ }_{15}$ Appian, $B C, 1.9$.

${ }^{16}$ Isaac 1990,141 , note 199.

${ }^{17}$ AE 1939180.

${ }^{18}$ Millar 1993, 34-35 contra Isaac 1990, 143 who argues there is insufficient evidence to consider Palmyra civitas stipendiaria in the 1 st $\mathrm{C}$ and civitas libera in the 2 nd C AD.

${ }^{19}$ Isaac 1990, 143.

${ }^{20}$ AE 1933, 207; Isaac 1990, 143, note 217.
} 
The first record of Palmyrene soldiers within the Roman army is limited to the military diplomas discovered in Dacia, dated AD 120 and $126^{21}$. Textually, it is stipulated that the holder is granted Roman citizenship, however mentions like ante emerita stipendia, conubium, indication of troops other than the beneficiary's as well as the name of the unit commander are lacking. Although tempting explanations were given ${ }^{22}$, the grant, under special conditions, of Roman citizenship to Palmyrene archers must be related to the status which Palmyra enjoyed within the Roman Empire by the beginning of Hadrian's reign.

The practice of imparting Roman citizenship to soldiers after a certain delimited period (in this case, after 6 years) is specific to foederata cities or communities linked to Rome by a foedus. Only these soldiers had such rights and, we shall see below, palmyreni sagittari together with the mauri equites are most relevant examples ${ }^{23}$.

Two inscriptions discovered at Palmyra, honouring two prefects of the Palmyrenes from Porolissum ${ }^{24}$ are also interesting. They are important to our discussion for two reasons. First of all, we note that the archers stationed in Dacia maintained relations with their area of recruitment and secondly, we remark that the Palmyrenes, alike the Batavians, were led by a native, although such fact is not laid down within the text of the military diplomas from AD 120 and 126.

Palmyra becomes colonia rather late, under Septimius Severus or Caracalla ${ }^{25}$. Only one family of senators is known from there, Septimus Odaenathus's father being the first of this rank $^{26}$. The most important fact, which must be related to the recruitment of the first Palmyrenes in the Roman army, is the emergence of equestrian rank officers starting with the 2 nd C. They served in units specific to Palmyrene soldiers, like the ones of sagittari or drommedari ${ }^{27}$.

The city also has some architectonical peculiarities, lacking certain public edifices like the baths, the hyprodrome or the theatre. It seems that the urban development of Palmyra was much more influenced by the nomad life style of the desert populations than the Hellenistic or Roman schematism. Concerning its demography, recent calculation indicates that the population of the urban centre reached 40000-60000 individuals in the 2nd C., hence a density of approximately $100-150$ people/ha ${ }^{28}$.

Thus we can appreciate the Palmyrenes case as different from that of the Batavians. From the insofar available data, it results that the Palmyrene society was not affected by troops supply to the Romans. Palmyra continued to develop, becoming a grand urban centre in a rather short time span. The city remains engaged in the caravan trade even after disturbances subsequent Trajan's Parthian war $^{29}$ and it is possible, at least under Hadrian, that diplomatic action was taken to protect Palmyrene merchants even when they transited territories not under Roman

\footnotetext{
${ }^{21}$ CIL XVI 68 = IDR I 6 (Porolissum-120); RMD I 17 = IDR I 5 (Caşei-120); RMD II 102, no. 2 = Petolescu 1973, 1020-1023 (Românaşi-120); RMD I 27 = IDR I 8 (Tibiscum -126); RMD I 28 = IDR I 9 (Tibiscum-126).

22 Mann, appendix RMD II 217.

${ }^{23}$ Le Roux 1986, 358-359 and 370; for the Mauri, Hamdoune 1999, 166-167; Onofrei 2007, 270-272.

${ }^{24}$ IDRE II 413 (M. Ulpius Abgarus) and AE 1947170 = IDRE II 414 (T. Aelius....).

${ }^{25}$ Millar 1990, 39.

${ }^{26}$ Gawlikowski 1985, 257-260.

${ }^{27}$ Isaac 1990, 225, note 37.

${ }^{28}$ Savino 1999, 75.

${ }^{29}$ Trajan wanted to change the trade routes of the Near East, more precisely, to exclude Babylonia by diverting trade routes through Armenia. Thus, caravan cities from the area and the Jews (who were engaged in the trade between the two empires) lost a great deal following this revision. The situation in the area was reestablished by Hadrian, Rome preserving only Arabia, specifically for maintaining trade control with China and India (Neusner 1979, 58). The basis of the Silk Road was set after Mithridates's II conquests by negotiation with the Han dynasty, as the trade with the Mediterranean world brought substantial income (Rey-Coquais 1978, 55). Thus, we believe that covenants were more likely closed under Hadrian rather than his predecessor, at least from a commercial standpoint. See also Février 1931, 19-24 and 117-126 who mentions that Palmyra, subsequently Trajan's Eastern campaign, preserved a fairly independent status specific to several Greek cities of the Empire.
} 
$\operatorname{control}^{30}$. Another advantage is represented by citizenship granting after a short while and additionally, the access to equestrian militiae. In their turn, the Romans benefited of units that could be stationed in certain strategic points within border provinces, like Dacia ${ }^{31}$, ffrica $^{32}$ or Egypt $^{33}$. Likewise, they could be stationed in farther garrisons like Dura Europos ${ }^{34}$.

Citizenship imparting is limited to the soldier only (not to his family also), thus the excessive extension of Roman citizenship within the periphery areas of the Empire was avoided $^{35}$. On the other hand, ethnical units were easier to support financially compared to an ala or a cohors equitata and were often much more efficient ${ }^{36}$. In exchange to efficient and cheaper recruits, the Romans offered citizenship after a short period of time and certain economic advantages to the city, which preserves until late the control over the caravan trade on certain routes. Moreover, a series of Palmyrenes accede to the equestrian and later on, to the senatorial ranks. Therefore, settlements were advantageous to both parties as Rome did not wish to impose its exclusive will.

\section{THE MAURI}

The third example in our presentation is represented by the Mauri. As early as the republican regime, temporary units of soldiers coming from the north-African region, like for instance the Numidian cavalry known during the Punic wars, are recorded. Although once with Augustus's reforms, the auxiliaries begin to be officially recognized ${ }^{37}$, the Romans used in parallel the warrior skills of several populations. Terms like gentiles or nationes practically designated the soldiers originating from various tribes, recruited from among the populations by the Empire borders or even outside them. Recruitment was made either by volunteering or as peace term between Rome and such populations ${ }^{38}$. Among them counted the Numidians, the Mauri or the Gaetulii, reknown especially as horsemen ${ }^{39}$.

The Mauri, alike the Palmyrenes, were not established in alae or cohorts in a first phase. A Mauri expeditionary force led by Lucius Quietus is recorded in the case of the first Dacian and the Parthian wars. Lucius Quietus must be seen as a princeps at the command of his soldiers, the term (princeps) being recorded early in the northern region of Africa (princeps Musulamiorum $)^{40}$.

Other information comes from Volubilis, where Aelius Tuccuda, princeps gentis Baquatium, honours Antoninus Pius ${ }^{41}$. He is a Roman citizen, most probably received under Hadrian and his gesture indicates the recognition of former alliances between gens Baquates and Rome. The remaining inscriptions (datable in the interval Marcus Aurelius-Probus) from Volubilis were

\footnotetext{
${ }^{30}$ Complete discussion in Seyrig 1941, 155-175; see also Seyrig 1941a, 228.

${ }^{31}$ Numerus Palmyrenorum Porolissensium, numerus Palmyrenorum Tibiscensium, numerus Palmyrenorum $O(\ldots)$, Petolescu 2002, 138-143; Țentea 2008.

${ }^{32}$ Numerus Palmyrenorum-El-Kantara, Equini Schneider, 1987, 383-395.

${ }^{33}$ Hadriani Palmyreni Antoniniani sagittarii are stationed at Koptos beginning with AD 216, Speidel 1992a, 82-85.

${ }^{34}$ Cohors XX Palmyrenorum, Kennedy 1983, 214-216.

${ }^{35}$ Forni 1992, 324-390; Kerneis-Poly 1996, 92-94. See also the case of the Mauri (infra) and data on the Edict of Caracalla, since citizenship granting targeted mainly certain soldiers and their families.

${ }^{36}$ The fact may be noted at Koptos. Ala Vocontiorum was camped here until AD 183, when changes garrison with ala Thracum Herculanea from Palmyra. From AD 216, the Thracian unit is replaced with a troop of Palmyrene archers (Speidel 1992a, 82-85). We notice that cavalry units are replaced, starting with the 3rd C, even though they were troops which had stationed until then in various strategic points.

${ }^{37}$ Feugère 1993, 47-50.

${ }^{38}$ Speidel $1977,715$.

${ }^{39}$ Hamdoune 1999, 66-78 (with bibliography).

40 Tacitus, Annales, IV, 24, 2: principes Musulamiorum defectionem coepiantis securi percutit.

${ }^{41}$ Hamdoune 1999, 153.
} 
dedicated by Roman governors on the occasion of the so-called colloquia pacis, into which princeps gentis/gentium ${ }^{42}$ also participated.

Another case is represented by gens Zegrenses, a tribe from Mauretania Tingitana whose princeps is known to have received Roman citizenship under Marcus Aurelius, fact which did not imply that the Romans decreased the tribute they levied ${ }^{43}$.

Although researchers' views on the legal status of several tribes from Mauretania are conflicting $^{44}$, it is certain that the Romans controlled a series of territories with their help. Citizenship granting was restricted only to the leader, like the cases presented above. The fact that the tribes were led by a princeps and not a king may however, provide indication to their dependence to Rome.

There is knowledge that a war took place in Mauretania under Antoninus Pius ${ }^{45}$. The conflict was ample since units from the two Pannonias, Moesias and Noricum were involved ${ }^{46}$. We are not sure on the position certain tribes from Mauretania adopted towards this conflict, since Pausanias describes the Mauri as nomads, forming large part of the independent tribes from Lybia ${ }^{47}$. However, the above example of Aelius Tuccuda and the religious practices of the Mauri stationing, once with Antoninus Pius's Principate, at Micia, in Dacia, contradict the fact they would originate from nomad tribes ${ }^{48}$.

Consequent the conflict from Mauretania, we should mention two military diplomas discovered in Dacia. The first diploma found at Cristeşti, dated in July $8158^{49}$ mentions (5-6 intrinsecus, 7-10 extrinsecus) vexillariis Africae et Mauretaniae Caesariensis qui sunt cum Mauris gentilibus in Dacia superiore. Here may be distinguished detachments of regular troops from Africa and Mauretania Caesariensis, indicated as vexillariis and an irregular formation of Mauri, gentiles, of a different status compared to the rest of the mentioned units ${ }^{50}$. The following text is legible on the second diploma ${ }^{51}$ discovered at Răcari, dated also under Antoninus Pius: Mauris eq[uit(ibus) et pedit(ibus)?] qui sunt in [Moe]sia Sup[(eriore)]. The fragment, today lost, allowed the interpretation [Dac]ia Sup[er(iore)] ${ }^{52}$, more suitable within the context of the previously presented diploma, however not entirely certain. Nonetheless, Mauri units were not identified insofar in Moesia Superior ${ }^{53}$.

The Mauri troop mentioned by the diploma discovered at Cristeşti is considered to have been formed after the war that Antoninus Pius waged in Mauretania, the last being war

\footnotetext{
${ }^{42}$ Lewin 1994, 112 (with the bibliography on the inscriptions).

${ }^{43}$ Lewin 1994, 115.

${ }^{44}$ Lewin 1994, 114 (with bibliography).

${ }^{45}$ Pausanias 8.43.5; SHA, Ant. Pius 5, 4

${ }^{46}$ Speidel 1977, 132.

${ }^{47}$ Pausanias 8.43.5.

48 Onofrei 2007, 278, it is less likely that soldiers coming from Berber tribes defeated by the Romans, had already been romanized, erecting votive altars and epitaphs and moreover, being interested and showing piety towards divinities adored in centres like Lambaesis and Lepcis Magna.

${ }^{49}$ CIL XVI 108 = IDR I 16; Petolescu 2002, 134-138.

${ }^{50}$ Three alae- I Batavorum, I Hispanorum Campagonum, I Gallorum et Bosporanorum, three cohorts- I Thracum, IV Hispanorum, I Augusta Ituraeorum and these vexillarii Africae et Mauretaniae Caesariensis qui sunt cum Mauris gentilibus in Dacia superiore.

${ }^{51}$ CIL XVI 114 = IDR I 29; Petolescu 2002, 134; Benea 1986, 141-142.

${ }^{52}$ Nemeth 1997, 103.

${ }^{53}$ For auxiliaries (recorded within military diplomas) from the two Moesias, see: Matei-Popescu, Țentea 2006, $102-108$. Cohors Maurorum milliaria is mentioned within a military diploma (AE 2002, 1237) found at Kostolac/ViminaciumMoesia Superior. The name of the holder reads: T(ito) Flavio (Titi) f(ilio) Titiano Bassian(a). However, the diploma text indicates that the constitution was issued for the troops in Pannonia Inferior, hence without relation to the auxiliaries from Moesia Superior. Moreover, the holder reminds he is from Bassiana, in Pannonia. There are no epitaphs or votive altars dedicated by soldiers from the Mauri units, like in Dacia.
} 
prisoners ${ }^{54}$. The remaining text of the second diploma is yet similar to the diplomas granted to the Palmyrenes, the ethnical name preceeding the specialty in both.

Christine Hamdoune does not consider the completing et pedites necessary, the author concluding that a foedus ${ }^{55}$ was closed between the Mauri and Rome. Thus, the Mauri gentiles from the diploma at Cristeşti may be seen as voluntaries recruited from among communities not abiding to the Roman law, however allied with Rome. The fact may be supported also by the existent relations between Rome and tribes like Baquates or Zegrenses.

Returning to the diploma from Răcari, it is more logical that it mentioned only Mauri equites and not pedites also, given that the Mauri were mainly used as horsemen. Their fighting style and military equipment does not seem to have changed over the time since the representation of Mauri riders on Trajan's column ((LXIV) is strikingly similar to that on a funerary monument ${ }^{56}$ erected for a soldier at Neapolis/Palestina, Augindai (with specific African anthroponim) dated in AD 194.

It is considered that Mauri gentiles are the basis for the numeri units attested in several locations from Dacia. Considering the high number of troops formed of Mauri (numerus Maurorum Miciensium, numerus Maurorum Tibiscensium, numerus Maurorum Hispanensium, numerus Maurorum S(...), all in Dacia Superior, a numerus Maurorum Optatianensium in Dacia Porolissensis and a numerus Maurorum $\Sigma(\ldots)$ in Dacia Inferior $)^{57}$ we may conclude that, beginning with Antoninus Pius, the Mauri were recruited massively. Beside the units from Dacia, we could also add cohors milliaria Maurorum equitata and cohors quingenaria Maurorum equitata $^{58}$ recorded in Pannonia, numerus Maurorum Aurelianorum documented in Brittania ${ }^{59}$, as well as cohors IX Maurorum Gordiana, which is known to have stationed at Hatra, probably until 240, when the area enters under Sassanid rule ${ }^{60}$.

The above data make us appreciate that the Romans preferred to keep under control a series of tribes from Mauretania through which they further dominated a vast area, difficult to access to Roman troops. In exchange recognition of the alliance with Rome, a series of tribe chiefs received Roman citizenship. The citizenship was conferred only to the princeps and not to his subjects, who in certain cases paid tribute. In many cases, tributum could have additionally consisted in recruits and Roman authorities might have abused of such entitlement ${ }^{61}$. However, recruitment was not an issue since it is known that Roman Africa was densely settled, only Lepcis Magna and the territory afferent to the city being populated by circa 170.000 individuals under the Antonini and Septimius Severus ${ }^{62}$.

This situation is possible to have changed after Antoninus Pius's war in Mauretania, as the diploma from Răcari, which records the Mauris equites, may infer that a significant number of Mauri soldiers received Roman citizenship according to a foedus entered between them and Rome. Should we agree with the similarities between the diploma from Răcari and those granted to the Palmyrenes, in both the ethnic name preceeding the specialty, we could assume

\footnotetext{
${ }^{54}$ Speidel 1975, 209; Southern 1989, 93, the author considers that the first were recruited from troops stationed in northern Africa and Mauretania to ensure the command of such gentiles.

${ }^{55}$ Hamdoune 1999, 154-155.

${ }^{56} \mathrm{AE} 1948148$.

${ }^{57}$ Petolescu 2002, 134-138, Onofrei 2007, 269-282.

${ }^{58}$ Lörincz 2001, 38-39, (cohors milliaria Maurorum equitata no. 33), (cohors quingenaria Maurorum equitata no. 34).

${ }^{59}$ Holder 1982, 126.

${ }^{60}$ Gawlikowski 1994, 47.

${ }^{61}$ It is hard to believe that the tribute of tribes from Mauretania was perceived in money and not recruits like in the case of rich regions from Asia Minor, where mandatory recurrent recruitment is changed, in some cases, to a money tax, see Mitchell 1994, 143-147 for a series of such examples.

${ }^{62}$ Savino 1999, 129.
} 
that this is the case of Roman citizenship granting to specialised soldiers, cheaper than those from regular auxiliaries and probably more efficient. Although existing sources are limited, we note that Roman ingenuity functioned in the case of the Mauri also. Alike with the Batavi, the Romans did not invest much in keeping an area under control. They limited to granting Roman citizenship to local leaders, through which they ensured the security of an area hard to defend.

\section{THE GOTHS}

The last population used as example in our study are the Goths. Archaeological data show that a series of sites pertaining to the Wielbark culture identified along rivers Bug and San, Vistula tributaries, may be dated in the chronological interval B2/C1a (AD 160-220). Finds related to the Wielbark culture were also signalled in Volhynia and north Ukraine, datable in the chronological interval $\mathrm{C} 1 \mathrm{a} / \mathrm{C} 1 \mathrm{~b}(\mathrm{AD} 180-220)$ as well as south Ukraine, datable however slightly later, during $\mathrm{C} 2-\mathrm{C} 3$ (AD 250-300) ${ }^{63}$. The expansion of the Wielbark culture of the interval AD 150-220/230 was followed by the formation of the Černjachov culture, spread on large part of Ukraine and Romania ${ }^{64}$.

Beside archaeological discoveries, which identified sites connected to the Wielbark culture, written sources ${ }^{65}$ also record the first ample attack undertaken by the Goths in AD 238, when Histria was lost.

An inscription discovered in Arabia, at I'nāt, south Hāuran, close to Imtān (Motha) is however contradictory and reads as follows:

Monument of Guththa, son of Erminarius, commander of the tribal troops stationed among the Mothani. He died at the age of 14 years. In the year 102, Peritius the 21st (=February 28, AD 208) ${ }^{66}$.

Guththa, the first anthroponim of the text, is not a form of the semithic $\Gamma \alpha v^{\tau} \tau \varsigma^{67}$, but precisely the name of the Gothic population, used here as personal name ${ }^{68}$, while the father's name, Erminarius, is Germanic. Hence, Erminarius must be considered praepositus of some Gothi gentiles serving in AD 208 in Arabia ${ }^{69}$, since it is hard to believe that the troops which he commanded were local.

It is important to establish when the Romans entered in contact with the Goths in order to identify the area of their recruitment. A first contact is suppsed to have occurred during the Marcomannic wars, as the accounts from Historia Augusta make us believe that the Romans were aware of northern tribes' presence that pressured the Marcomanni and the Quadi ${ }^{70}$. Although the reference, however indirect, may point to the Goths, there is no data on their probable involvement in the conflict. Moreover, it is possible that the drafters of Historia Augusta used the 375 Goths withdrawal from the Huns as model, while the causes were in fact other ${ }^{71}$.

In fact, neither the archaeological finds place the Goths so close to the limes so that they would enter in contact with the Romans and it is hard to believe that among those led by

\footnotetext{
${ }^{63}$ Heather 1996, 38.

${ }^{64}$ Wolfram 1988, 42; Kazanski 1991, 18-28, 30; Kokowski 1999, 185-196 with a series of defining maps.

${ }^{65}$ SHA, Max. et Balb. 16. 3.

${ }^{66}$ Translation after Speidel 1977a, 712.

${ }^{67}$ Wuthnow 1931.

${ }^{68}$ Speidel 1977a, 712 uses for analogy the forms $\Gamma \alpha v \theta \theta \alpha 1 / \Gamma \alpha v \theta \theta 01$ recorded in Res Gestae Divi Saporis. See also: Maricq 1958, 295; Frye 1984, 371-373. Pollard 2000, 158 the name also appears in Syrian and is used precisely for designating soldiers coming from the west.

${ }^{69}$ Speidel 1977a, 712-713; Heather 1996, 39, Graf 1998, 21; fact also maintained by Wolfram 1988, 396-397, note 48, although he considers the attestation as very early.

${ }^{70}$ SHA Marcus Aurelius 14.1.

${ }^{71}$ Heather 1996, 35.
} 
Valerius Maximus ${ }^{72}$, praepositus equitibus gentium Marcommanorum, Naristorum, Quadorum, ad vinidictam orientalis motus pergentium, count also Goths ${ }^{73}$. The inscription of Valerius Maximus is however very suggestive in proving Rome's policy towards the defeated tribes. Those mentioned in the inscription were enrolled as prisoners for preventing rebellions by Lower Danube during the Eastern campaing of Marcus Aurelius. Beside being used as soldiers, they also aided in maintaining control over an area barely pacified.

Cassius Dio records that the Scythians $(\Sigma \kappa v \theta \alpha \imath)^{74}$ wished to begin hostilities against Septimius Severus, however a natural phenomenon made them reconsider, as three of their leaders were struck by lightning ${ }^{75}$. The event took place around AD 196, thus we may assume that beginning with this date the Goths get recruited in the Roman army ${ }^{76}$. M. P. Speidel, based on the inscription, concludes that the Goths' stationing in Arabia must have been earlier than AD 208 and relates their presence there to the second Parthian campaign of Septimius Severus $(197-199)^{77}$. The same author argues that the passage in Cassius Dio infers that the Goths also provided hostages or recruits to Septimius Severus and that this was the main reason for which they did not initiate attack $^{78}$.

It is known that the Romans controlled many tribes beyond the limes, interfering in their policies even though no garrison was placed in respective area. This could be the case of the Goths, who provide recruits to the Roman army either following a covenant (foedus) or as term of peace with the Romans. Since we do not know for certain whether there was a war between Septimius Severus and the Goths ${ }^{79}$, the first variant seems more likely. Similarly, it is hard to belive that those mentioned in the inscription from Arabia are mercenaries, as the latter appear mentioned as salariarii. They were temporarily enrolled and alike the evocati, received money (salaria instead of stipendium) for various fulfilled tasks ${ }^{80}$.

Under Caracalla, the Goths presence in the Roman army is signalled again. Sources ${ }^{81}$

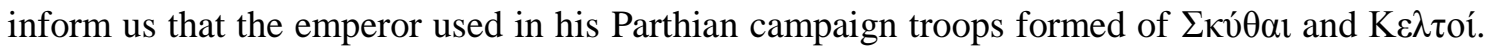
Their leaders become centurions and a part are even chosen to join the personal guard of the

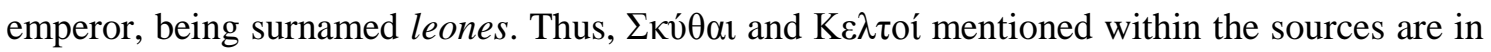
fact the Goths and Alamanni, barbarian populations behind the northern limes involved in AD 217 in the campaign against the Parthians ${ }^{82}$. After Caracalla's murder, Macrinus sees himself compelled to fight once more with the troops of Artabanus V, who demanded the withdrawal of the Roman troops behind the Euphrates. The Goths were among the amassed troops, as in 218

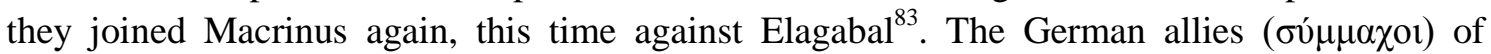
Caracalla and subsequently of Macrinus must have been a military unit, their role being different from that of a simple personal guard, a fact supported by the promotion of its leaders as centurions ${ }^{84}$.

Other data on the Goths presence in the Roman army are inexistent until the Parthian campaign of Gordian III. Beside the Romans, among the populations defeated by Shapur I in

\footnotetext{
${ }^{72}$ AE 1956, 12 inscription datable in AD 175.

${ }^{73}$ Graf 1998, 21 considers the above troops of Gothic origin.

${ }^{74} \Sigma \kappa v \theta \theta \alpha$ designates the Goths within Greek classical sources.

${ }^{75}$ Cassius Dio 75, 3.

${ }^{76}$ Heather 1996, 39.

77 Speidel 1977a, 714.

${ }^{78}$ Speidel 1977a, 714.

${ }^{79}$ Speidel 1977a, 714, note 110

${ }^{80}$ Speidel 1992b, 76.

${ }^{81}$ Cassius Dio 78, 5; Herodian 4, 7, 3.

${ }^{82}$ Speidel 1975, 226-227; Speidel 1977a, 714; Graf 1998, 21.

${ }^{83}$ Herodian 5, 4, 8.

${ }^{84}$ Speidel 1975, 227.
} 
AD 244 counted also the Goths and the Germans (Gwt W Grm'ny) $)^{85}$. The source relays that the Goths contribution in Gordian III's army was significant and that in general a distinction was made between the Goths and other Germanic peoples. We note that once with the Severan dynasty, the Goths serve in the Roman army, being used both in campaigns and border areas, as shown by the inscription from Arabia.

We may consider that, once with the Marcomannic wars, the role of the cavalry and various barbarian populations within the Roman army is increasingly of the essence. A first example are the troops led by Valerius Maximus, praepositus equitibus gentium Marcommanorum, Naristorum, Quadorum, populations which are firstly defeated and subsequently enrolled in the Roman army. Under the Severians, a foedus between the Goths and the Romans most likely existed, the first providing soldiers to the army as Rome allies. We know however, that after Macrinus was defeated, Elagabal sends the German troops home ${ }^{86}$, while they are no longer found in the army used by Severus Alexander for his campaigns, the emperor engaging recruits from Italy and other provinces, among which are also attested the Mauri equites and the Oshroeni archers ${ }^{87}$.

Although the 234 turmoil, which resulted in the assassination of Severus Alexander, is ascribed to the Alamanni, the Goths attack Histria no later than 238, after which they withdraw. During their short joint reign, Pupienus and Balbinus send general Menophilus against the Goths, who restores order. The Romans undertook to provide subsidies to the Goths and the latter, most probably troops in exchange ${ }^{88}$. This would explain the Goths presence in the army of Gordian III. The 238-248 attacks are no longer related to the Goths, but to the Carpians, discontent because the Romans had refused to pay them subsidies as well. The Carpians are defeated by Philip the Arab, who celebrated his success in 246 and 248. The arrangements with the Goths do not function past 248 as Philip the Arab, either for financial reasons, as the Roman withdrawal from Mesopotamia had been bought with 500.000 denarii ${ }^{89}$ or due to the success against the Carpians, refuses to pay further subsidies to the Goths. The consequences of this decision would be critical and in AD 251, at Abbritus, Roman troops would be defeated and Emperor Decius killed ${ }^{90}$.

Thus, first contacts between the Romans and the Goths could have occurred in the chronological interval $\mathrm{C} 1 \mathrm{a} / \mathrm{C} 1 \mathrm{~b}$ ( $\mathrm{AD} 180-220$ ), when the latter were, in a first phase, to the north of the Carpathians and subsequently north the Black Sea ${ }^{91}$. Their constant presence as allies within the armies of Septimius Severus, Caracalla, Macrinus and Gordian III, makes us conclude that a foedus operated between the Goths and the Romans. According to this foedus, the Goths provided the Romans with troops, receiving in exchange subsidies, definitely from Gordian III. It is hard to establish the impact of successive recruitment over the Goths. Late sources tend to inflate numbers, since it is hard to believe that after the foedus of 332 , Constantine had received 40000 soldiers $^{92}$. A parallel with year 365, when Procopius obtained only 3000 Goths as troops, denotes that numbers must have been the same also for earlier periods $^{93}$. Being often used as soldiers in various campaigns, the barbarians beyond the limes are

\footnotetext{
${ }^{85}$ For Res Gestae Divi Saporis, see: Maricq 1958, 295; Frye 1984, 371-373.

${ }^{86}$ Cassius Dio, 80, 4, 5.

${ }^{87}$ Southern 2001, 61-62.

${ }^{88}$ Wolfram 1988, 44; Southern 2001, 222.

${ }^{89}$ Millar 1993, 153-154.

${ }^{90}$ For the Roman's wars with the Goths until Alaric, see: Kulikowski 2007.

$\square$ Godłowski 1994, 70-73; Kokowski 1999, 185-196.

92 Iordanes, Getica 21,112

${ }^{93}$ Heather 1999, 57-66.
} 
increasingly allured by the luxury, goods and life style of the Romans, who would be gradually forced to accept their peaceful or violent presence.

In conclusion, based on the four examples, we attemped to show the way that the Romans used the warrior skills of certain subdued populations or with whom they entered in contact. In parallel, we tried to observe the impact of recruitment over respective societies and their influence on the evolution of the Roman society in its turn.

In the case of the Batavians, we noticed that the Romans encouraged the preservation of the military character of their society and that they used their warrior skills, recruiting a large number of units stationing in a first phase on the Rhine and in Britannia. By recruiting them in auxiliaries, the Romans earned a significant number of soldiers, without levying taxes in exchange. An expedient situation for the Empire, which neither intervined nor invested in the development of the community until late. As we have seen in other cases as well, the elite were coopted by the Romans, the Batavian leaders becoming Roman military leaders over the time. However, the fact that the majority of the communities from border areas turn into militarised societies is best observed in the Batavians case. They are used in the Roman army until late, Batavian units being also known in Late Antiquity ${ }^{94}$, when the structure of the Roman army had changed.

Compared to the Batavians, the Palmyrenes seem to have enjoyed a special status, probably favoured by the role that Palmyra played within the caravan trade, as well as the circumstances of their recruitment. The military diplomas afforded to the Palmyrenes mark a change in the Roman view on the recruitment, fitting and use of auxiliaries. Once with Hadrian, specialised units emerge in border areas of the Empire. Although inferior as status in a first phase, in time they would become customary within the army and would eventually replace part of regular auxiliaries. Both parties benefited: in exchange the contribution of specialised soldiers, the Romans offered citizenship after a determined period. Beside the economic advantages which the city enjoyed, Roman citizenship opened the way to equestrian militiae.

The Mauri are the closest example to that of the Palmyrenes. It is recognized they fulfilled a double role, being used both in campaigns as well as fixed garrison units in border regions. They were also massively recruited, alike the Batavians, and only the leaders of various tribes received Roman citizenship, however, beginning with Antoninus Pius, their role within the Roman army became increasingly essential. The diploma discovered at Răcari (see supra), presenting similarities with those granted to the Palmyrenes, probably indicates also the Roman citizenship granting. The situation must not be excluded since the Palmyrenes could have been a good example, being admitted that Antoninus Pius rallied to his predecessor's policy. The Mauri also provide military corps until late, alike the Batavians, yet, compared to the latter, as temporary units ${ }^{95}$.

Once with changes occurring in the structure of the Roman army, often caused by necessity, we notice the increase of the number of specialised and barbarian units. We chose the case of the Goths, who, as we have seen, are involved in campaigns starting with the 3rd C. They are also foederati, however the Romans paid them subsidies in exchange of troops. Beginning with the Goths, almost all known tribes beyond the northern limes would provide units to the Roman army. The presence of certain alae or cohorts composed of Alamanni, Goths, Franks or Iuthungi is signalled in Eastern provinces like Syria, Oshroene and Mesopotamia ${ }^{96}$. However, the payment of subsidies and the recurring conflicts of the Romans with populations coming from the north do not imply that force poles had reversed. Covenants were never closed

\footnotetext{
${ }^{94}$ Zuckerman 1993, 17-18.

${ }^{95}$ Southern, Dixon 1996, 65.

${ }^{96}$ Pollard 2000, 29-30.
} 
on equal footing for as long as Rome was a force, however differences from a population to the other existed, as observed in our study as well. Although the term of foedus appears in sources only in the 4th C, foederati existed as early as the Principate, preceding the later allies of the Romans.

\section{BIBLIOGRAPHY}

Alföldy 1968 - G. Alföldy, Die Hilfstruppen der römischen Provinz Germania Inferior, Epigraphische Studien 6, Düsseldorf.

Benea 1986 - Doina Benea, Numerus Maurorum Tibiscensium. Contribuții la istoria trupelor de mauri din Dacia, Banatica, 8, 139-154.

Birley 2002 - A. Birley, Garrison Life at Vindolanda. A Band of Brothers, Tempus/England.

Cheesman 1914 - G. L. Cheesman, The Auxilia of the Roman Imperial Army, Oxford.

Derks 1997 - T. Derks, Gods, Temples and Ritual Practices. The Transformation of Religious Ideas and Values in Roman Gaul, Amsterdam.

Derks 2009 - T. Derks, Ethnic identity in the Roman frontier. The epigraphy of Batavi and other Lower Rhine tribes, Ethnic Constructs in Antiquity. The Role of Power and Tradition (ed. T. Derks, N. Roymans), Amsterdam, 239-282.

Equini Schneider 1987 - Eugenia Equini Schneider, Palmireni in Africa, L'africa romana. Atti del V convegno di studio Sassari, 11-13 dicembre 1987 (ed. Attilio Mastino), 1987, 383-395.

Feugère 1993 - M. Feugère, Les armes des Romains de la Republique à l'Antiquité tardive, Paris, 1993. Février 1931 - J. G. Février, Essai sur l'histoire politique et économique de Palmyre.

Forni 1992 - G. Forni, Contributo alla storia della Dacia romana, Esercito et marina di Roma Antica: Raccolta di Contributi, Mavors Roman Army, vol. V, Stuttgart, 1992, 324-390.

Frye 1984 - R. N. Frye, The History of Ancient Iran, München.

Gawlikowski 1985 - M. Gowlikowski, Les princes de Palmyre, Syria 62, 251-261.

Gawlikowski 1994 - M. Gawlikowski, A Fortress in Mesopotamia: Hatra, The Roman and Byzantine Army in the East. Procedings of a colloqium held at the Jagellonian University, Kraków in September 1992 (ed. E. Dabrowa), Kraków, 47-56.

Godłowski 1994 - K. Godłowski, Die Barbaren nördlich der Westkarpaten und das Karpatenbecken Einwanderungen, politische und militärische Kontakte, Specimina Nova 9, 65-89.

Graf 1998 - F. G. Graf, Foederati on the Northen and Eastern Frontiers. A Comparative Analysis, The second International Symposium (Murighiol/Halmyris 18-24 August 1996). Studia Danubiana Pars Romaniae series symposia I. The Roman Frontier at the Lower Danube 4th-6th centuries, Bucharest, 17-31. Hamdoune 1999 - Christine Hamdoune, Les auxilia externa africains des armées romaines. III siècle av. J.-C. - IV siècle ap. J. - C., Montpellier.

Haynes 2001 - I. P. Haynes, The Impact of auxiliary recruitment on provincial societies from Augustus to Caracalla. Administration, Prosopography and Appointment Policies in the Roman Empire. Proceedings of the first workshop of the international network: Impact of Empire (Roman Empire 27 B. C.-A. D. 406), Leiden, June 28-July 1, (ed. L. de Blois), Amsterdam, 62-83.

Heather 1996 - P. J. Heather, The Peoples of Europe. The Goths, Blackwell-Oxford.

Heather 1997 - P. J. Heather, Foedera and foederati of the fourth century, Kingdoms of the Empire. The Integration of Barbarians in Late Antiquity (ed. W. Pohl), Leiden, 57-74.

Holder 1980 - P. A. Holder, The Auxilia from Augustus to Trajan, Oxford, BAR IS 70.

Holder 1982 - P. A. Holder, The Roman Army in Britain, New York.

Isaac 1990 - B. Isaac, B., The Limits of Empire. The Roman Army in the East, Oxford.

Kazanski 1991 - M. Kazanski, Les Goths ${ }^{\mathrm{er}}-\mathrm{VII}^{\mathrm{e}}$ siècles après J.-C., Paris.

Kennedy 1983 - D. L. Kennedy, Cohors XX Palmyrenorum - an alternative explanation of the numeral, ZPE 53, 214-216. 
Kerneys-Poly 1996 - S. Kerneys-Poly, Les numeri ethniques de l'armée romaine aux IIe-IIIe siècles, RSA 26, 69-94.

Knight 1991 - D. J. Knight, The Movements of the Auxilia from Augustus to Hadrian, ZPE 85, 189208.

Kokowski 1999 - A. Kokowski, Vorschlag zur relativen Chronologie der südöstlichen Kulturen des Gotenkreises (Die Forschungsergebnisse der Masłomęcz-Gruppe in Polen), Die Sîntana de MureşČernjachov-Kultur. Akten des Internationalen Kolloquiums in Caputh vom 20. bis 24. Oktober 1995 (ed. G. Gomolka-Fuchs), Bonn, 179-210.

Kulikowski 2007 - M. Kulikowski, Rome's Gothic Wars, Cambridge.

Le Roux 1986 - P. Le Roux, Les Diplômes militares et l'évolution de l'armée romaine de Claude à Septime Sévère: auxilia, numeri et nationes, Heer und Integrationspòlitik: die römische Militärdiplome als historische Quelle, Köln-Wien, 347-374.

Lewin 1994 - A. Lewin, The Organization of a Roman Territory: the southern section of provincia Arabia, The Roman and Byzantine Army in the east. Proccedings of a colloquim held at the Jagellonian University, Kraków in September 1992 (ed. E. Dabrowa), Kraków, 109-118.

Lőrincz 2001 - B. Lőrincz, Die römischen Hilfstruppen in Pannonien während der Prinzipatszeit, Wien. Maricq 1958 - A. Maricq, Res Gestae Divi Saporis, Syria 35, 295-360.

Matei-Popescu, Țentea 2006 - Fl. Matei-Popescu, O. Țentea, Participarea trupelor auxiliare din Moesia Superior şi Moesia Inferior la cucerirea Daciei, Dacia Augusti Provincia, 75-120.

Millar 1990 - F. Millar, The Roman Coloniae in the Near East. Roman Eastern Policy and Other Studies in Roman History. Proceedings of a Colloquium at Tvärminne 2-3 october 1987, (H. Solin, M. Kajava ed.), Helsinki, 7-57.

Millar 1993 - F. Millar, The Roman Near East, 31 BC-AD 337, London.

Mitchell 1994 - Mitchell, S., Notes on Military Recruitment from the Eastern Roman Provinces, The Roman and Byzantine Army in the east. Proccedings of a colloqium held at the Jagellonian University, Kraków in September 1992 (ed. E. Dabrowa), Kraków, 141-148.

Nemeth 1997 — Nemeth, E., Die numeri im römischen Heer Dakiens, EN 7, 101-116.

Neusner 1979 - Neusner, J., The Jews East of the Euphrates and the Roman Empire, I. $1^{\text {st }}-3^{\text {rd }}$ Centuries A. D., ANRW II. 9. 1, 46-69.

Onofrei 2007 - C. Onofrei, Maurii în Dacia, RB 21, 1, 269-282.

Petolescu 1973 - C., C. Petolescu, Palmyreni sagittarii dans un nouveau diplôme militaire de la Dacie Supérieure, Latomus 34, 4, 1020-1023.

Petolescu 2002 - Petolescu, C.C., Auxilia Daciae. Contribuții la istoria militară a Daciei romane, Bucureşti.

Pollard 2000 - Pollard, N., Soldiers, Cities, and Civilians in Roman Syria, Michigan.

Raepsaet-Charlier 1995 - M. -Th. Raepsaet-Charlier, MunicipiumTungrorum, Latomus 54, 361-369.

Rey-Coquais 1978 - J.-P. Rey-Coquais, Syrie romaine, de Pompée à Dioclétien, JRS 68, 44-73.

Roymans 1983 - N. Roymans, The North Belgic tribes in the $1^{\text {st }}$ century BC. A historicalanthropological perspective, Roman and native in the Low Countries. Spheres of interaction, BAR IS 184, 43-69.

Roymans 1990 - N. Roymans, Tribal societies in Northern Gaul. An anthropological perspective, Cingula 12, Amsterdam.

Saddington 1975 - D. B. Saddington, The Development of the Roman Auxiliary forces from Augustus to Trajan, ANRW II.3, 176-201.

Saddington 2005 - D.B. Saddington, The Roman Government and the Roman Auxilia, Limes 19 Pècs, 6369.

Savino 1999 - E. Savino., Città di frontiera nell'impero romano. Forme della romanizzazione da Augusto ai Severi, Bari.

Seyrig 1941 - H. Seyrig, Le statut de Palmyre, Syria 22, 155-175.

Seyrig 1941a - H. Seyrig, Inscriptions greques de l'Agora de Palmyre, Syria 22, 223-270.

Southern 1989 - P. Southern, The Numeri of the Roman Imperial Army, Britannia 20, 81-140.

Southern 2001 - P. Southern, The Empire from Severus to Constantine, London-New-York. 
Southern, Dixon 1996 - P. Southern, R. K. Dixon, The Late Roman Army, London.

Speidel 1975 - M. P. Speidel, The rise of Ethnic Units in the Roman Imperial Army, ANRW II, 3, $201-231$.

Speidel 1977 - M. P. Speidel, Pannonian troops in the Moorish war of Antoninus Pius, Limes 11 Székesfehérvár, 129-136.

Speidel 1977a - M. P. Speidel, The Roman Army in Arabia, ANRW II.8, 1977, 687-730.

Speidel 1992 - M. P. Speidel, Germani Corporis Custodes, RAS II, Stuttgart, 105-119.

Speidel 1992a - M. P. Speidel, Palmyrenian Irregulars at Kaptos, RAS II, 82-85.

Speidel 1992b - M. P. Speidel, The Rise of the Mercenaries in the Third Century, RAS II, 71-81.

Țentea 2008 - O. T,entea, Trupele siro-arabe de pe limesul dunărean al Imperiului Roman, Diss., ClujNapoca.

Van Enkevort 2005 - H. van Enkevort, The significance of the building activities of Trajan and the Legio X Gemina for the integration of the Batavians of the Roman Empire, Limes 19 Pècs, 85-91.

Willems 1984 - W. J. H. Willems, Romans and Batavians. A regional study in the Dutch eastern river area II, BROB 34, 39-331.

Wolfram 1988 - H.Wolfram, History of the Goths, Los Angeles-London.

Wuthnow 1931 - R. Wuthnow, Die semitischen Menschennamen in griechischen Inschriften und Papyri des vorderen Orients, Leipzig.

Zuckerman 1993 - C. Zuckerman, Les Barbares romains: au sujet de l'origine des auxilia tétrarchiques, L'armée romaine et les barbares du IIIe au VIIe siècle (ed. F. Vallet, M. Kazanski), 17-20. 